\title{
TINGKAT KERENTANAN MASYARAKAT TERHADAP PERUBAHAN IKLIM DI KECAMATAN XIII KOTO KAMPAR, PROVINSI RIAU
}

\section{(Level Of Community Vulnerability On Climate Change In District XIII Koto Kampar, Province Of Riau)}

\author{
Enny Insusanty ${ }^{1}$, Muhammad Ikhwan ${ }^{1}$, Ervayenri $^{1}$ dan Emy Sadjati ${ }^{1}$ \\ ${ }^{l}$ Staf Pengajar Fakultas KehutananUniversitas Lancang Kuning \\ Jln. Yos Sudarso Km 8 Rumbai Pekanbaru Telp (0761) 54092 \\ E-mail : ennyinsusanty@unilak.ac.id,erva@unilak.ac.id,mmighwan@unilak.ac.id,emy@unilak.ac.id
}

Diterima: 19 Februari 2020, Direvisi: 17 Maret 2020, Disetujui: 17 Maret 2020

DOI: https://doi.org/10.31849/forestra

\begin{abstract}
This research was conducted to determine the exposure, sensitivity and adaptation of the community in mitigating climate change and to obtain a map of the level of vulnerability of the community in mitigating climate change. This study uses secondary data and primary data with the survey method using a questionnaire of 75 respondents by purposive sampling which is a community in 3 (three) villages in District XIII Koto Kampar. In addition, in-depth interviews were conducted with village heads, farmer groups, community leaders and focus group discussions. Data processing is done by Excel, software Arc Gis 9.3 to obtain a map of the level of vulnerability of the community. Data analysis was carried out descriptively. The level of exposure and sensitivity of Pulau Gadang Village, Koto Mesjid and Tanjung Alai are included in the criteria of moderate. For the level of adaptation measured by the criteria of health, education, electricity and road infrastructure of Pulau Gadang Village and Koto Masjid, the criteria are rather high, while Tanjung Alai Village is of moderate criteria. The level of vulnerability in the three villages includes the level of moderate vulnerability
\end{abstract}

Keywords: climate, exposure, sensitivity, adaptation, vulnerability

\begin{abstract}
ABSTRAK
Penelitian ini dilakukan untuk mengetahui keterpaparan, sensitifitas dan adaptasi masyarakat dalam mitigasi perubahan iklim serta diperoleh peta tingkat kerentanan masyarakat dalam mitigasi perubahan iklim. Penelitian ini menggunakan data skunder dan data primer dengan metode survei menggunakan kuesioner sebanyak 75 orang responden secara purposif sampling yang merupakan masyarakat di 3 (tiga) desa di Kecamatan XIII Koto Kampar. Selain itu juga dilakukan pengambilan wawancara mendalam kepada kepala desa, kelompok tani, tokoh masyarakat dan FGD. Pengolahan data dilakukan dengan excel, software Arc Gis 9.3 untuk memperoleh peta tingkat kerentanan masyarakat. Analisis data dilakukan secara deskriptif. Tingkat keterpaparan dan sensitifitas Desa Pulau Gadang, Koto Masjid dan Tanjung Alai termasuk pada kriteria sedang. Untuk tingkat adaptasi yang diukur dengan kriteria fasilitas kesehatan, pendidikan, listrik dan infrastruktur jalan Desa Pulau Gadang dan Koto Masjid termasuk kriteria agak tinggi sedangkan Desa Tanjung Alai dengan kriteria sedang. Tingkat kerentanan pada ketiga desa tersebut termasuk pada tingkat kerentanan sedang
\end{abstract}

Kata kunci : iklim, keterpaparan, sensitifitas, adaptasi, kerentanan 


\section{PENDAHULUAN}

Kegiatan manusia telah menyebabkan terjadinya peningkatan emisi Gas Rumah Kaca (GRK) yang menimbulkan terjadinya fenomena pemanasan global dan mengakibatkan terjadinya perubahan iklim. Perubahan iklim terjadi secara perlahan-lahan namun pasti. Selain itu, perubahan iklim memberikan dampak pada semua sektor kehidupan. Sebagai negara yang rentan terhadap perubahan iklim Indonesia di wilayah Asia diprediksi terjadi peningkatan suhu $2-6^{0} \mathrm{C}$ dan curah hujan lebih banyak (Herawaty \& Santoso, 2007). Perubahan ini memberikan peluang peningkatan bencana klimatis seperti kekeringan dan banjir yang diakibatkan oleh perubahan suhu dan pola curah hujan (Tim Sintesis Kebijakan Departemen Pertanian, 2008)

Peran hutan dalam mitigasi dapat dilihat dari fungsi sebagai penyerapan karbon, melalui penanaman campuran (jenis kayu pertukangan, pakan ternak, buah-buahan dan lain-lain). Kedua terhadap fungsi perlindungan seperti bahaya erosi, longsor dan pengurangan bahaya kebakaran dan serangan hama penyakit dengan pencampuran berbagai jenis tanaman dan yang ketiga terhadap fungsi pemanfaatan energi yang dapat diperbaharui, dengan tanaman jenis penghasil kayu bakar.

Peran-peran tersebut selama ini kurang disadari oleh masyarakat, terutama di daerah-daerah. Seiring dengan semakin gencarnya issue pemanasan global dan perubahan iklim, membuat masyarakat sedikit demi sedikit mulai mengerti bahwa dampak negatif dari pemanasan global ini telah mereka rasakan.

Degradasi lingkungan menyebabkan ekosistem tidak dapat optimal menyediakan fungsi dan jasa yang sangat penting bagi kehidupan manusia. Kondisi ini menyebabkan penurunan tingkat kesejahteraan masyarakat dan meningkatkan tingkat kerentanan masyarakat. Kerentanan masyarakat merupakan kondisi masyarakat yang tidak dapat menyesuaikan dengan perubahan ekosistem yang disebabkan oleh suatu ancaman tertentu. Upaya penguatan agroforestri yang dilakukan sebagai upaya mitigasi iklim diharapkan dapat memberikan pengaruh positif kepada masyarakat. Penelitian ini bertujuan untuk mengetahui sensitifitas dan adaptasi masyarakat dalam mitigasi perubahan 
iklim sehingga diperoleh peta tingkat kerentanan masyarakat dalam mitigasi perubahan iklim.

\section{METODE PENELITIAN}

Kegiatan penelitian ini dilakukan di Kecamatan XIII Koto Kampar Kabupaten Kampar, Provinsi Riau pada bulan Februari - Juni 2018. Kecamatan XIII Koto Kampar, Kabupaten Kampar. Lokasi penelitian dipilih secara sengaja (purposive sampling) karena masyarakatnya sebagian besar mengembangkan tanaman karet yang dilakukan secara monokultur maupun agroforestri di lahan milik mereka. Tiga desa yang menjadi fokus dalam kegiatan ini adalah Desa Pulau Gadang, Desa Koto Masjid, dan Desa Tanjung Alai.

Penelitian ini menggunakan metode survei dengan kuesioner sebanyak 75 orang responden secara purposif sampling yang merupakan masyarakat di 3 (tiga) desa di Kecamatan XIII Koto Kampar kepada. Selain itu juga dilakukan pengambilan wawancara mendalam kepada kepala desa, kelompok tani dan tokoh masyarakat dan FGD. Pengolahan data dilakukan dengan excel, software Arc Gis 9.3 untuk memperoleh peta tingkat kerentanan masyarakat.

Untuk menentukan penilaian kerentanan masyarakat terhadap perubahan iklim, maka digunakan tiga komponen yaitu paparan, kepekaan, dan kemampuan adapatasi. Analisis indikator kepekaan masyarakat terhadap perubahan iklim menggunakan metode kualitatif dengan pendekatan studi literatur. Indikator kerentanan masyarakat terhadap perubahan disajikan pada tabel 1 .

Tabel 1. Indikator Keterpaparan dan Sensitivitas (IKS) dan Indikator Kemampuan Adaptasi (IKA)

\begin{tabular}{|c|c|c|}
\hline \multirow[t]{2}{*}{ No } & \multicolumn{2}{|c|}{ Jenis Indikator (Indicator Type) } \\
\hline & $\begin{array}{l}\text { Indeks Keterpaparan dan Sensitivitas } \\
\text { (Exposure and Sensitivity Index) }\end{array}$ & $\begin{array}{l}\text { Indeks Kemampuan Adaptasi } \\
\text { (Adaptability Ability Index) }\end{array}$ \\
\hline 1 & $\begin{array}{l}\text { Kepala Keluarga tinggal di pinggir sungai } \\
\text { (the family lives by the river) }\end{array}$ & Fasilitas Listrik (Electricity Facility) \\
\hline 2 & $\begin{array}{l}\text { Jumlah bangunan di pinggir sungai } \\
\text { (Number of buildings on the riverbank }\end{array}$ & $\begin{array}{l}\text { Fasilitas Pendidikan } \\
\text { (Educational facilities) }\end{array}$ \\
\hline 3 & $\begin{array}{l}\text { Sumber Air Minum } \\
\text { (Source of Drinking Water) }\end{array}$ & Fasilitas Kesehatan (Health facility) \\
\hline 4 & Kepadatan Populasi (Population Density) & Infratruktur jalan (Road Infrastruktur) \\
\hline 5 & Tingkat Kemiskinan (Poverty level) & \\
\hline
\end{tabular}




\section{$6 \quad$ Fraksi luas sawah \\ (Extensive fraction of rice field) \\ $7 \quad$ Fraksi areal pertanian \\ (Farm area fraction) \\ 8 Mata pencaharian utama (Main livelihood)}

Penilaian kerentanan masyarakat terhadap perubahan iklim menggunakan fungsi dari tiga komponen, yaitu singkapan, kepekaan, dan kemampuan adaptasi (IPCC 2001; O'Brien et al. 2004; Metzeger et al. 2006 dalam Forner 2006). Untuk menghasilkan peta tingkat kerentanan masyarakat terhadap perubahan iklim, dilakukan langkah-langkah sebagai berikut ini :

\section{Penentuan Indeks Kerentanan}

Untuk menentukan Indeks Kerentanan dilakukan dengan mengurangi hasil jumlah Indeks Paparan dan Kepekaan dengan Indeks Kemampuan Adaptasi. Rumus yang digunakan adalah :

$$
\text { Indeks Kerentanan }(\mathrm{IK})=\text { SEI }- \text { ACI }
$$

Dimana :

$$
S E I=\sum_{j=1}^{n} w_{i j}^{*} I_{S E i j}
$$

dan

$$
A C I_{i}=\sum_{j=1}^{n} w_{i j} * I_{A C i j}
$$

keterangan :

a. SEI adalah indeks paparan dan kepekaan b. ACI adalah indeks kemampuan adaptasi

c. Wij adalah bobot indicator ke $\mathrm{i}$ pada paparan

\section{Pembuatan Peta Kerentanan}

Hasil analisis kerentanan masyarakat ditampilkan dalam bentuk peta-peta dengan bantuan program pemetaan yaitu Arc Gis 9.3. Peta yang dihasilkan adalah peta paparan, kepekaan, kemampuan adaptasi, dan kerentanan. Peta paparan, kepekaan dan kemampuan adaptasi diperoleh dengan operasi join table atau add field pada tiap indikator pada peta-peta yang telah ditumpangtindihkan dengan peta administrasi wilayah penelitian. Peta kerentanan masyarakat terhadap erubahan iklim diperoleh dengan operasi overlay atau tumpang tindih antara peta paparan, peta kepekaan masyarakat dan peta kemampuan adaptasi.

Data yang diperoleh dari lapangan kemudian dianalisis secara deskriptif kualitatif dan kuantitatif untuk mengetahui tujuan utama masyarakat dalam pengelolaan agroforestri dan sejauh mana 
persepsi dan pengetahuan masyarakat terhadap mitigasi perubahan iklim.

\section{HASIL DAN PEMBAHASAN}

Kerentanan masyarakat adalah kondisi masyarakat yang tidak dapat menyesuaikan dengan perubahan ekosistem yang disebabkan oleh suatu ancaman tertentu (Fussel, 2007). Kerentanan merupakan fungsi dari tiga komponen, yaitu exposure (paparan), sensitivity (kepekaan), dan adaptive capacity (kemampuan adaptasi) (IPCC, 2001). Faktor keterpaparan sensitivitas terhadap perubahan iklim di tiga desa di Kecamatan XIII Koto Kampar dipengaruhi oleh 8 (delapan) variabel dengan hasil analisis sensitivitas disajikan pada tabel 2.

Tabel 2. Tingkat Keterpaparan dan Sensitivitas Masyarakat di Lokasi Penelitian

\begin{tabular}{llrrr}
\hline & & \multicolumn{3}{c}{$\begin{array}{c}\text { NILAI INDIKATOR PER DESA } \\
\text { (Value Of The Village Indicators) }\end{array}$} \\
\cline { 3 - 5 } No & VARIABEL (Variables) & \multicolumn{2}{c}{ TANJUNG } & \multicolumn{2}{c}{ PULAU } & \multicolumn{1}{c}{ KOTO } \\
& & ALAI & GADANG & \multicolumn{1}{c}{ MASJID } \\
\hline 1 & Jumlah Bangunan Dipinggir & 0,0005 & 0,0005 & 0 \\
& Sungai & 0,001 & 0,001 & 0 \\
2 & Kk Tinggal Dipinggir Sungai & 0,1 & 0,1 & 0,1 \\
3 & Sumber Air & 0,0435 & 0,0345 & 0,045 \\
4 & Kepadatan Populasi & 0,13 & 0,070164 & 0,04 \\
5 & Tingkat Kemiskinan & 0 & 0 & 0 \\
6 & Fraksi Luas Sawah & 0,0055 & 0,0065 & 0,0075 \\
7 & Fraksi Areal Pertanian & 0,095 & 0,09 & 0,07 \\
8 & Mata Pencaharian & 0,3755 & 0,302664 & 0,2625 \\
& Jumlah & Sedang & Sedang & Sedang \\
\hline
\end{tabular}

Berdasarkan hasil pengolahan data keterpaparan dan sensitivitas diperoleh kondisi masyarakat berada pada kriteria sedang dengan kisaran nilai $0,25-0,50$. Dari indikator pada setiap variabel diperoleh jumlah bangunan yang berada dipinggir sungai terdapat di dua desa yaitu
Pulau Gadang dan Tanjung Alai sebanyak $1 \%$ sedangkan di Desa Koto Masji tidak terdapat bangunan yang berada dipinggir sungai dengan radius $<100 \mathrm{~m}$. Demikan juga halnya dengan jumlah Kepala Keluarga (KK) yang berada di pinggir sungai memiliki indikator dengan 
nilai yang sama dimana hanya ada di Desa Pulau Gadang dan Tanjung Alai.

Sumber air yang digunakan oleh masyarakat memiliki nilai sama yaitu 0,1 dimana hanya ada 1 sumber utama penggunakan air yaitu bersumber dari sumur bor yang dibuat oleh masyarakat. Sebagian masyarakat ada yang menggunakan sumber lain yaitu sungai namun jumlahnya hanya sedikit.

Kepadatan populasi dari setiap desa dengan melihat jumlah penduduk dan luas desa, dimana berdasarkan penilaian kriteria diperoleh nilai yang paling terpapar dan sensitif adalah Desa Koto Masjid karena memiliki kepadatan yang lebih tinggi yaitu, diikuti oleh Desa Pulau Gadang dan Tanjung Alai. Vorosmarty (2000) menunjukkan peningkatan jumlah penduduk dan ekonomi menjadi pendorong utama kebutuhan air, sementara itu ketersediaannya dipengaruhi oleh peningkatan evaporasi (penguapan) akibat peningkatan temperatur permukaan bumi. Daerah-daerah dengan kepadatan penduduk tinggi akan memiliki tingkat kepekaan lebih tinggi dibandingkan daerah-daerah yang lainnya.
Tingkat kemiskinan diukur berdasarkan jumlah KK miskin yang terdapat pada ketiga desa tersebut dimana Desa Tanjung Alai memiliki nilai dengan indikator paling banyak penduduk miskin. Tingkat kesejahteraan masyarakat menentukan tingkat sensitifitas terhadap perubahan iklim.

Penggunaan lahan pertanian di ketiga desa adalah areal perkebunan dan peranian lahan kering dan tidak terdapat sawah. Selain itu juga dikembangkan areal perikanan yang sangat tergantung pada sumber air. Mata pencaharian masyarakat sangat tergantung pada alam dengan jenis pekerjaan adalah petani dan tambak ikan sehingga memiliki keterpaparan dan sensitifitas yang cukup besar. Pemetaan kepekaan masyarakat terhadap perubahan iklim dipengaruhi oleh tingkat kepadatan penduduk, akses terhadap air bersih dan ketergantungan masyarakat terhadap lahan (Effendi, dkk. 2012).

Pada masyarakat yang memiliki ketergantungan pada lahan akan lebih membutuhkan air yang lebih banyak. Jenis pakerjaan masyarakat ini umumnya pada sektor pertanian (pertanian, kehutanan, perkebunan, perikanan). Peningkatan suhu 
menyebabkan tanaman atau tumbuhan membutuhkan air yang semakin tinggi. Selain itu, ketersediaan air yang berlimpah pada musim hujan (banjir) dapat menyebabkan para petani mengalami resiko kegagalan panen yang tinggi (Swandayani, 2010)

Sebanyak $53 \%$ masyakat memiliki sumber pendapatan ganda dan sisanya memperoleh pendapatan hanya dari 1 sumber. Namun demikian, sumber mata pencaharian mereka sangat bergantung terhadap sumberdaya alam sehingga berkontribusi tinggi terhadap tingkat

berkontribusi tinggi terhadap tingkat sensitivitasnya. Secara umum sumber pendapatan masyarakat berasal dari hasil pertanian, perkebunan dan perikanan.

Secara keseluruhan ketiga desa dalam penelitian termasuk pada kategori sedang untuk keterpaparan dan sensitifitas terhadap perubahan iklim dengan desa yang memiliki tingkat keterpaparan dan sensitifitas paling tinggi adalah Desa Tanjung Alai karena memiliki tingkat kemiskinan tertinggi dan mata pencaharian penduduk dengan tingkat ketergantungan pada alam paling tinggi.

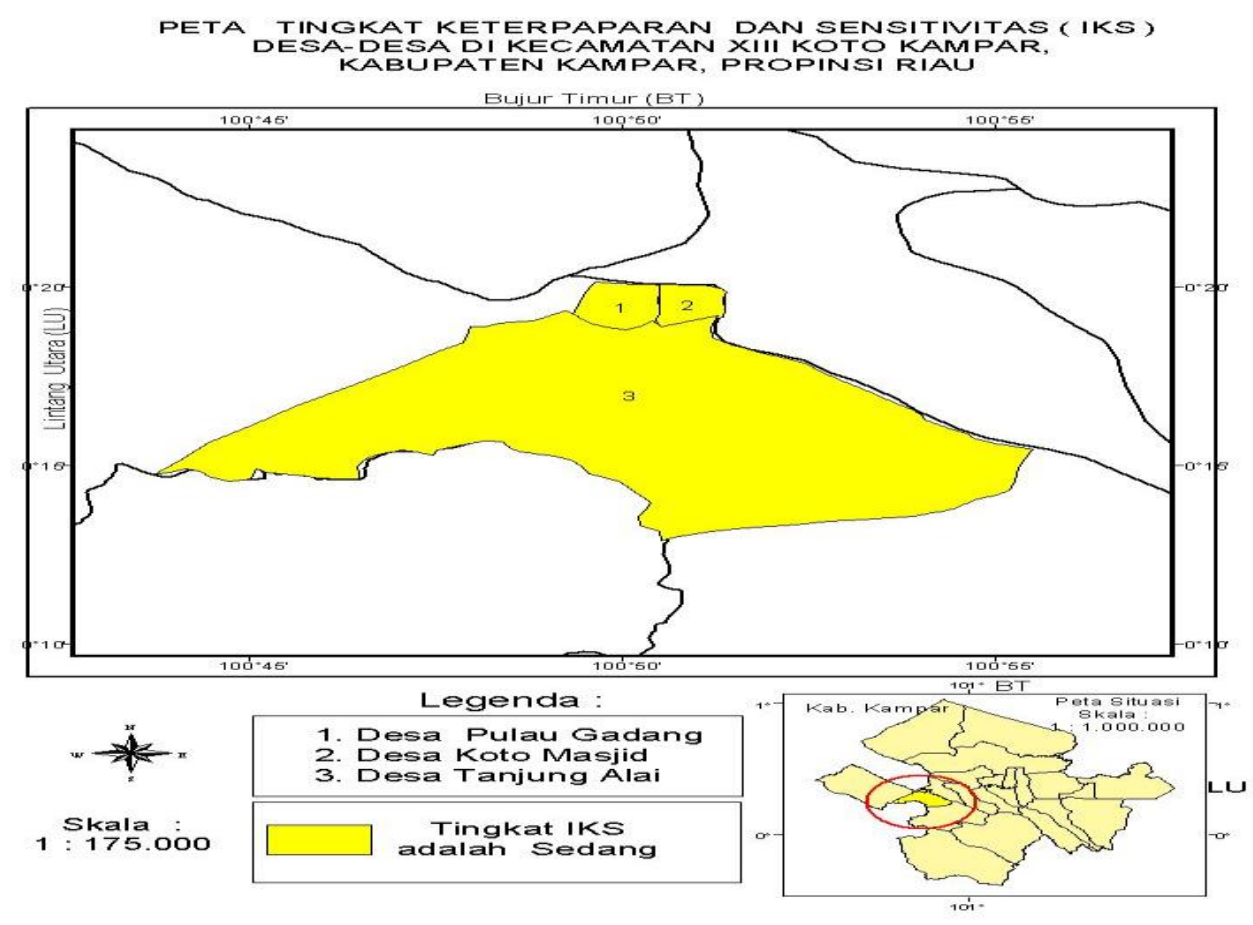

Gambar 1. Peta Tingkat Keterpaparan dan Sensitivitas 
Tabel 3. Tingkat Adaptasi Masyarakat di Lokasi Penelitian

\begin{tabular}{llccc}
\hline \multirow{2}{*}{ No } & \multirow{2}{*}{$\begin{array}{c}\text { VARIABEL } \\
\text { (Variables) }\end{array}$} & \multicolumn{2}{c}{$\begin{array}{c}\text { NILAI INDIKATOR PER DESA } \\
\text { (Value }\end{array}$} \\
\cline { 3 - 5 } & & $\begin{array}{c}\text { TANJUNG Tillage Indicators) } \\
\text { ALAI }\end{array}$ & $\begin{array}{c}\text { PULAU } \\
\text { GADANG }\end{array}$ & $\begin{array}{c}\text { KOTO } \\
\text { MASJID }\end{array}$ \\
\hline 1 & Fasilitas Listrik & 0,178 & 0,18 & 0,194 \\
2 & Fasilitas Kesehatan & 0,075 & 0,075 & 0,125 \\
3 & Fasilitas Pendidikan & 0,1 & 0,1675 & 0,05 \\
4 & Infrastruktur jalan & 0,15 & 0,15 & 0,15 \\
& Jumlah & $\mathbf{0 , 5 0}$ & $\mathbf{0 , 5 7}$ & $\mathbf{0 , 5 1}$ \\
& Kriteria & sedang & agak tinggi & agak tinggi \\
\hline
\end{tabular}

Berdasarkan tabel 3 diperoleh adaptasi disetiap desa yang menjadi objek penelitian yaitu Desa Pulau Gadang dan Koto Masjid memiliki tingkat adaptasi agak tinggi sedangkan Desa Tanjung Alai kapasitas adaptasi sedang dengan nilai 0,50. Nilai ini dipengaruhi dari 4 faktor yaitu fasilitas listrik, kesehatan, pendidikan dan infrastruktur jalan. Pembangunan infrastruktur merupakan salah satu solusi yang cepat untuk adaptasi perubahan iklim namun dapat memberikan dampak negatif jika tidak direncanakan dengan baik (Swandayani, 2011).

Untuk fasilitas listrik nilai yang paling tinggi adalah Desa Koto Masjid karena sudah mencapai $97 \%$ memiliki aliran listrik. Fasilitas kesehatan paling lengkap adalah Desa Koto Masjid dengan adanya puskesmas dan klinik kesehatan. Sedangkan untuk fasilitas pendidikan paling lengkap ada di Desa Pulau Gadang karena memiliki SMU, SMP dan SD. Infrastruktur jalan yang melintasi ke tiga desa sama dimana sudah memiliki infrastruktur jalan sebesar 50\%. Adapun faktor aksesibilitas dinilai baik, ditunjukkan dengan akses jalan aspal dan perkerasan sampai ke pemukiman terdalam.

Berikut gambar peta adaptasi perubahan iklim disajikan pada Gambar.2 


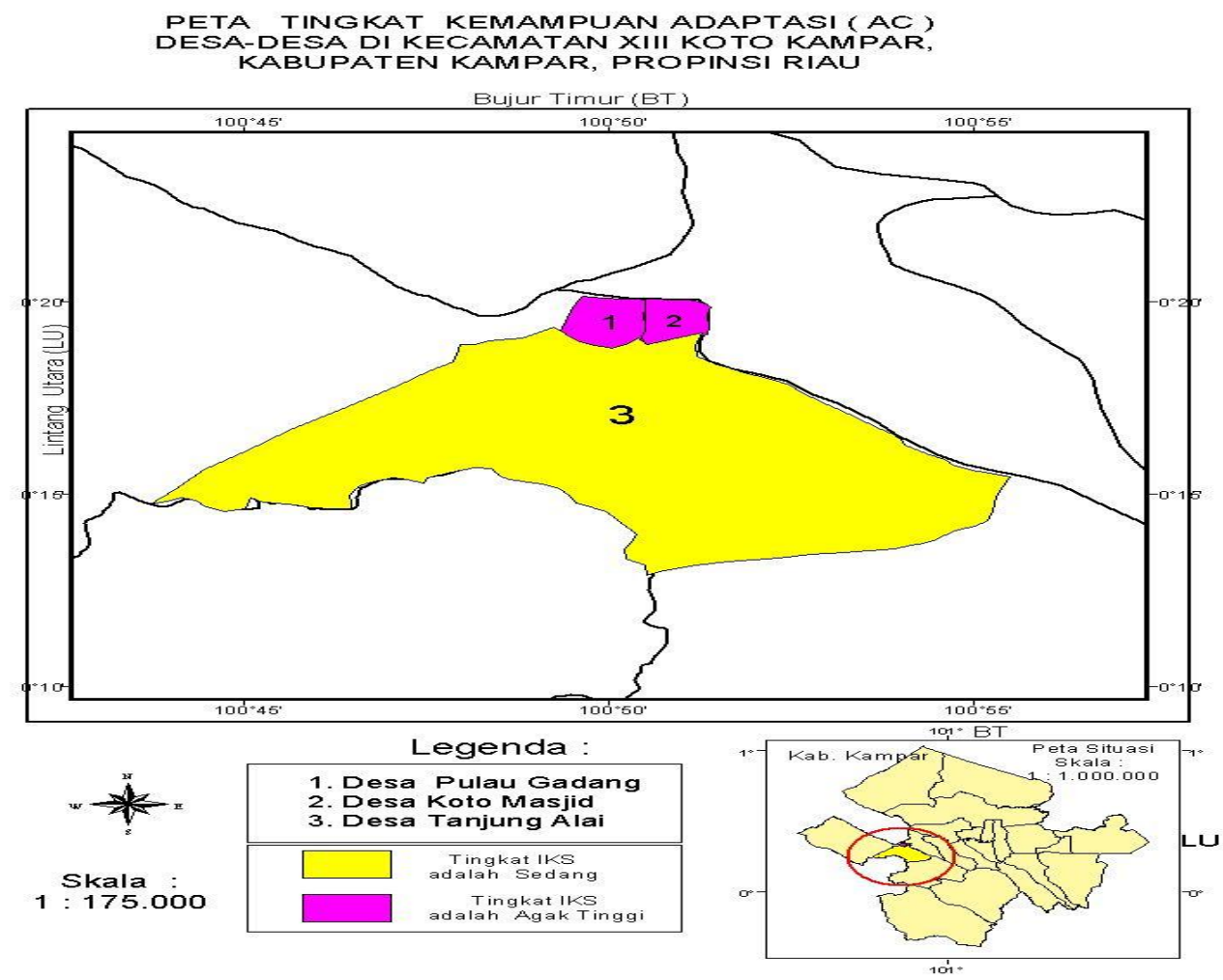

Gambar 2. Peta Tingkat Kemampuan Adaptasi

Tabel 4. Klasifikasi Tingkat Kerentanan

\begin{tabular}{|c|c|c|c|}
\hline NO & Desa (Villages) & IKS & IKA \\
\hline 1 & Tanjung Alai & Sedang (moderate) & Sedang (moderate) \\
\hline 2 & Pulau Gadang & Sedang (moderate) & Agak tinggi (rather high) \\
\hline 3 & Koto Masjid & Sedang (moderate) & Agak tinggi (rather high) \\
\hline
\end{tabular}

Didasarkan pada IKS dan IKA diperoleh peta kerentanan ke 3 desa yang ada adalah seperti ditunjukkan pada tabel 4, maka berdasarkan matriks tingkat kerentanan (gambar 2) tingkat kerentanan dari ketiga desa tersebut digolongkan menjadi tingkat kerentanan sedang. Adapun peta kerentanan dapat dilihat pada gambar 


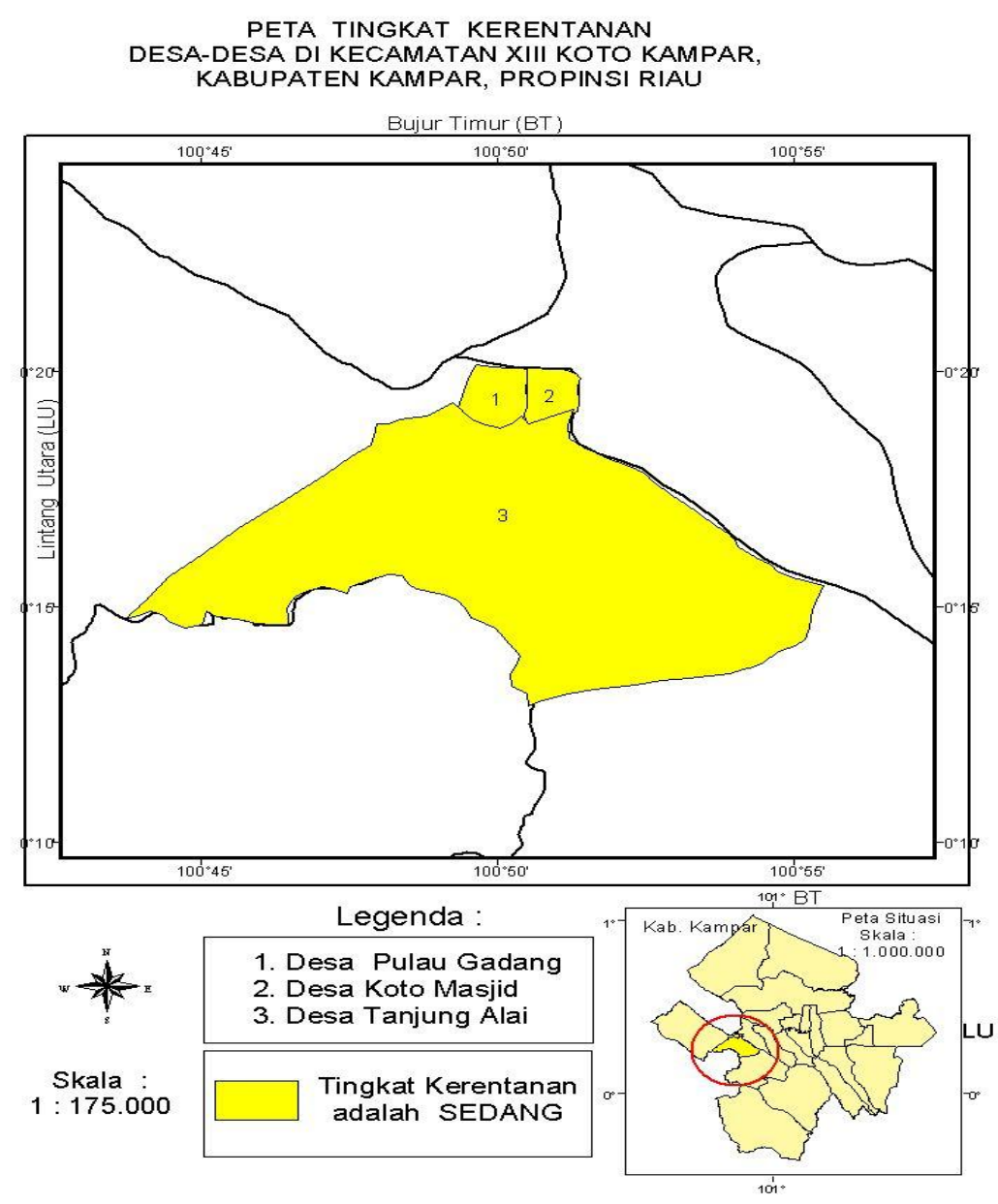

Gambar 3. Peta Tingkat Kerentanan

Tingkat kerentanan masyarakat terhadap perubahan iklim merupakan suatu kondisi dimana alam dan masyarakat tidak dapat menyesuaikan dengan dampak perubahan iklim (Fussel 2007). Dari hasil pemetaan kerentanan masyarakat teradap perubahan iklim diatas terlihat bahwa perubahan iklim bersifat global, tetapi tingkat kerentanan sistem alam dan masyarakat berbeda secara lokal. Gejala perubahan iklim menurut indikator klimatis teridentifikasi dalam skala global, dan bisa jadi tidak teridentifikasi dalam skala lokal (Pawitan, 2010). Selain itu Kec. XIII Koto Kampar rentan terhadap perubahan iklim atau singkapan meningkat lebih besar. Disadari bahwa tingkat kerentanan berbanding lurus dengan besarnya singkapan menunjukkan 
hubungan antar elemen kerentanan (Forner, 2006).

Kepekaan mempunyai hubungan yang sejajar dengan kerentanan, sebaliknya kemampuan adaptasi mempunyai hubungan terbalik dengan kerentanan. Disimpulkan bahwa tingkat kerentanan merupakan hubungan positif dari kepekaan masyarakat dan hubungan negatif dari kemampuan adaptasi masyarakat.

\section{KESIMPULAN DAN SARAN}

\section{A. Kesimpulan}

Tingkat keterpaparan dan sensitifitas Desa Pulau Gadang, Koto Masjid dan Tanjung Alai termasuk pada kriteria sedang. Untuk tingkat adaptasi yang diukur dengan kriteria fasilitas kesehatan, pendidikan, listrik dan infrastruktur jalan Desa Pulau Gadang dan Koto Masjid termasuk kriteria agak tinggi sedangkan Desa Tanjung Alai dengan kriteria sedang.

\section{B. Saran}

Diperlukannya suatu fasilitas kesehatan, pendidikan, listrik dan infrastruktur jalan didalam upaya mitigasi perubahan iklimdi Kecamatan XIII Koto Kampar, Riau

\section{UCAPAN TERIMA KASIH}

Terima kasih disampaiakn kepada Kemenristek Dikti yang telah mendanai penelitian ini sebagai bagian dari penelitian Model Agroforestri Dalam Upaya Mitigasi Perubahan Iklim Di Kecamatan XIII Koto Kampar, Riau.

\section{DAFTAR PUSTAKA}

Effendi M, Sunoko HR, Sulistya W.2012. Kajian Kerentanan Masyarakat Terhadap Perubahan Iklim Berbasis Daerah Aliran Sungai (Studi Kasus Sub Das Garang Hulu) Jurnal Ilmu Lingkungan Volume 10 Issue 1: 818

Herawaty , H dan H Santoso. 2007. Pengarus-utamaan adaptasi perubahan iklim ke dalam agenda pembangunan: tantangan kebijakan dan pembangunan. Adaptasi terhadap bahaya gerakan tanah di masa yang akan dating akibat pengaruh perubahan iklim. Laporan pertemuan dialog pertama gerakan tanah dan perubahan iklim. Bogor, tanggal 7-8 Desember 2006. Cifor. Bogor, Indonesia.

Forner C. 2006. An Introduction To The Impacts Of Climate Change And Vulnerability Of Forests. Background Document For The South East Asian Kick-Off Meeting Of The Project Tropical Forests And Climate Change Adaptation ("Trofcca"). Bogor, 29 - 30 Mei 2006. 
Fussel. H. Martin. 2007. Vulnerability: A Generally Applicable Conceptual Framework for Climate Change Research. Global Environment Change, 17 : 155-167.

IPCC (Intergovernmental Panel on Climate Change). 2001. Climate change 2001. Impacts, adaptation and vulnerability. Contribution of Working Group II to the Third Assessment Report of the Intergovernmental Panel on Climate Change. Cambridge University Press. Cambridge, UK.

Pawitan H. 2010. Arti Perubahan Iklim Global dan Pengaruhnya dalam Pengelolaan Daerah Aliran Sungai di Indonesia. Makalah pada Ekspose Hasil Litbang Balai Penelitian Kehutanan Solo dengan tema Pengelolaan DAS dalam Mitigasi dan Adaptasi Perubahan Iklim di Indonesia, di Surakarta pada tanggal 28 September 2010.

Swandayani. HT, 2010. Pemetaan Kerentanan Masyarakat Terhadap Perubahan Iklim Dan Adaptasi Berbasis Ekosistem Hutan (Studi Kasus : Das Ciliwung). Tesis Sekolah Pascasarjana Institut Pertanian Bogor

Swandayani HT, Purnomo.H, Kuncahyo B. 2011. Pemetaan Kerentanan Masyarakat Berbasis Ekosistem Hutan Terhadap Perubahan Iklim (Studi Kasus DAS Ciliwung, Jawa Barat). Jurnal Penelitian Sosial dan Ekonomi KehutananVol 8 No 1 Hal. 34-53
Tim Sintesis Kebijakan Departemen Pertanian. 2008. Dampak Perubahan Iklim Terhadap Sektor Pertanian, Serta Strategi Antisipasi dan Teknologi Adaptasi. Pengembangan Inovasi Pertanian 1 (2) 2008. Hlm 138-140. Balai Besar Penelitian dan Pengembangan Sumberdaya Lahan Pertanian. Bogor

Vorosmarty, C. J., Green, P., Salisbury, J. And Lammers, R.B. 2000. Global Water Resources: Vulnerability from Climate Change and Population Growth. J. Scienc. 289. $284-288$ 